\title{
The Relevance of Modern Technology Usage on the Business Ventures of Kenyan Women Entrepreneurs
}

\author{
Celestine Lugaye Ukpere
}

Cape Peninsula University of Technology Cape Town South Africa

Email: cukpere@gmail.com

Andre D. Slabbert

Cape Peninsula University of Technology Cape Town, South Africa

Email: slabberta@cput.ac.za

Wilfred I. Ukpere

Department of Industrial Psychology and people Management, University of Johannesburg, Johannesburg, Gauteng South Africa

Email:wiukpere@uj.ac.za

\section{Doi:10.5901/mjss.2014.v5n10p58}

\section{Abstract}

Technological advancement, the adoption of digital marketing and incorporation of digital platforms and websites have fundamentally changed the entrepreneurial landscape in Africa especially from a gender based perspective. Reduced data bundle rates, growth and spread of Internet use in Kenya has contributed to the development and incorporation of technology and digital tools by most women entrepreneurs in their business. During the last decade women based entrepreneurial ventures on the African continent has had to adapt and develop with the digital and modern technologies. This paper is a case study based on three business ventures, namely an informal small scale venture and two formal woman entrepreneurial ventures. The purpose of the paper was to establish the experiences of these women entrepreneurs with regards to their use of technology and digital marketing platforms, in order to ascertain their impact on the growth and development of their ventures. Incorporating technology tools in business has supported the survival and expansion of most Kenyan women entrepreneurs, through the creation of competitive advantages that allows and encourages prosperity within a global economic setting. This enables technology and digital marketing platforms to be categorised as an important strategic component and tool in modern commercial ventures. Women entrepreneurs on the African continent seem to have adapted to these new developments. This paper also reports specifically on the findings of an online survey conducted in Kenya in 2013, which investigated the experiences of women entrepreneurs in adapting and incorporating online social network platforms and digital tools in both the formal and informal sectors. This paper further explains the role digital technology tools such as ICTs, Online Marketing, and EMarketing including the Social media platforms, play to enhance Kenyan women entrepreneurial ventures.

Keywords: Social Media Platforms, ICTs, Web 2.0, Technology, Online Marketing, Online Strategy, Online social networking, Ecommerce, M-commerce, E-Marketing

\section{Introduction}

The $21^{\text {st }}$ century has been recognised as the women century, as women are now beginning to take prime position in business, and Kenya women are not excluded. According to the former Secretary General of the United Nations, Kofi Annan (cited in the International Center for Research on Women (ICRW), 2012:25), "There is no tool for development more effective than the empowerment of women ... and endeavors (that help) create intelligent gender-based perceptions about ICTs do play important roles to speed up developmental goals". The adaption and absorption in Africa of new information and communication technologies is quite slow as observed by Molony (2006). An information revolution has been sparked off by the growth of mobile phones leading to a transformation in usage and accessibility of the internet both by entrepreneurs and clients, who have taken up mobile phones to enable them to stay connected with friends and the use online payment solutions for transactions.

This new trend no doubt has enabled women entrepreneurs to change the way they work, and interact with their 
communities and networks (Komunte, Rwashana, \& Nabukenya, 2012 : 74). The correct technology when introduced and embraced by women entrepreneurs cedes positive economic and social remuneration for their immediate family, community and nation. Women's financial progression and entrepreneurial activity is supported through Information and communications technologies (ICTs), which include mobiles, computers devises and the Internet, which enable women entrepreneurs to experience advanced business practices, and severing gender barriers imposed due to tradition in both the social and economic spaces. However, the private sector is just beginning to see women as consumers- it has not yet fully realize the potential women entrepreneurs as a vibrant market. (ICRW, 2012: 3).

However, big brands and cooperation's have led the way in the use of Social Media platforms for the promotion and marketing of their products. For example, Coca Cola has ground breaking promotions that are fun and have interactive features on Facebook. In their summer snapshot promotions fans are persuaded to take pictures with the summer coke cans, which enable the product to be in-cooperated with the involved fans whose photos were uploaded. A viral effect takes place when the posted pictures are sent to newsfeeds since on Facebook, pictures are the main feature of communication for the fact that they are frequently viewed (Poterfield, 2010:1).

Nike is another big brand that has taken their social media campaign to the streets through their training applications which is portable work out training tool that enables their community to do it anywhere from iTunes (Rognerud, 2011:1). This aspect of big international brands using social platforms to their advantage has enabled the new upcoming women entrepreneurs in Africa to adopt this marketing model at a smaller scale. They have incorporated and adapted what works for them and improved on other aspects in their respective environments. Most of the women entrepreneurs own highly productive and innovative businesses ranging from small handicrafts, industrial machinery, skilled services, food and catering businesses, garment making, running a hotels to web portals. These women venture owners often act as role models for upcoming women entrepreneurs by leading them through the process of embracing social media and technology for their economic growth and success.

Modern Kenyan women entrepreneurs are able to unlock their financial growth and success through keeping up with the modern times and embracing ICT and other technologies as part of their business plans. The use of Twitter has been observed to be a growing trend for the youth to research and also market and advertise in real time etc. South Africa and Kenya have been respectively documented to be the highest Twitter users on the continent. Entrepreneurs have enabled many opportunities through the retail channels of Mobile Network Operators (MNO's), which has been made possible through the provision services such as education, health and aid distribution. Entrepreneurs have been encouraged to sell mobile products and take part in mobile money channels by joining MNO's retail channels, which have a wide reach that includes the rural environs. The position of distance is made irrelevant through the use of ICT and especially with mobile technology by global and transnational companies in managing production and business processes. Mobile phones have enabled entrepreneurs and the general masses to empower themselves, and to have access to information and data, which contribute economically and socially to communities with whom they are in touch with (Cherie Blair Foundation for Women (CBFW), 2011: 8).

The research has been carried out on formal and informal businesses that have embraced the World Wide Web (www), or social media platforms or both. The presence of formal and informal businesses can be found all over Africa and thanks to the power of the Internet and social media platforms. Currently, searching for diverse entrepreneurial ventures is no longer a daunting task. Both the informal and formal entrepreneurs who have embraced technology in the form of the internet and the use of digital marketing tools and platforms can be observed, documented and compared. This allows the comprehension of the role played by digital technology in form of E-commerce, M-commerce tools and platforms in the growth, expansion and success of entrepreneurs in Africa, particularly Kenyan women entrepreneurs, who have embraced and become very versed in the ways social platforms and digital applications enables them to get ahead of their peers.

These aspects when critically analysed will enable these established entrepreneurs and upcoming ones realise that just being on the social media platform will not grow their practises but practically taking an active role in engaging in these platforms is critical to their growth and expansion. Growth and success of entrepreneurship in sub-Saharan Africa is identified through the role played by budding entrepreneurs in the promotion and creation of wealth and in improving the living standards of ordinary Africans. Social restrictions and economic obstacles are removed through economic actions of entrepreneurs (Legatum, 2011: 1).

\section{Problem Statement}

There are few literatures available on this aspect of Kenyan women entrepreneurs taking advantage of Online Marketing, Online Strategy, Online social networking, E- commerce, M-commerce and E-Marketing in general to the maximum 
advantage. This is especially given the fact that the region has one of the cheapest cost and rates of data on the African continent. The outcome of this research will awaken a large and diverse number of Kenyan and African women entrepreneurs to embrace and adopt digital technology and social media platforms in a systematic way, in order to achieve entrepreneurial success of their ventures. Identifying the success rate through case studies of Kenyan women entrepreneurs using technology and digital platforms for e-marketing campaigns, E- commerce, and M-commerce for business transactions will enlighten other women entrepreneurs on how these can be applied to both formal and informal ventures.

\section{Research Questions}

The above statement led to the following research questions:

- Are Kenya women entrepreneurs effectively utilizing digital tools and other online marketing tools to enhance their ventures?

- Are the digital spaces and technology used to maximize business advantages by the women entrepreneurs in Kenya?

- How willing are the modern Kenyan entrepreneurs in investing resources towards social media to the advantage of their ventures?

- How can ICTs create and revolutionize entrepreneurial opportunities for women?

\section{Research Objectives}

The research objectives are:

- To establish how Kenya women entrepreneurs are effectively utilizing digital tools and other online marketing tools to enhance their ventures?

- To verify whether the digital spaces and technology have been properly used to maximize business advantages by the women entrepreneurs in Kenya.

- To established whether the modern Kenyan entrepreneurs are willing to invest resources towards social media to the advantage of their ventures?

- To find out how ICTs can create and revolutionize entrepreneurial opportunities for women?

\section{Literature Review}

Government statistics show that the informal sector, which is controlled by SMEs provides up to 90 percent of jobs for employees in Kenya. With an employment level of 60 percent in the country, the formula for the state's job creators is clearly seen. The undisclosed formula is the understanding and knowledge in the SME sector, an eagerness for taking calculated risks in an unpredictable setting, the ability to regularly reinvent and help friends and collaborators. This has been recognised as the formula of the world's successful entrepreneurs (Michira 2011:1). Micro-entrepreneurship has little impact, although it is well intentioned. African women entrepreneurs need to be supported to create scalable, successful businesses in order to achieve a greater impact in the communities where they operate (AfricaForbes, 2013: 96). The development and growth of small businesses that are owned by women is imperative and has been greatly enhanced through wireless technology. Both women and male entrepreneurs are creating jobs, hope and opportunities' in many societies across the globe. It has been noted that new information and technologies can be powerful components for increasing the effectiveness of countries and contributing towards financial growth and progress. The application or non-application of technology through e-commerce or m-commerce by entrepreneurial ventures in the modern digital world has a direct impact on the success or failure of these entrepreneurial ventures. These technological tools when applied under the right circumstances to the new enterprises provide competitive advantage and survival rate can be achieved. Developing and underdeveloped economies across the globe are getting the benefit of social and economic significance conception that is spreading innovation, technical and entrepreneurial skills through the web and mobile technology in constructing products and content that are relevant to them (WebFoundation, n.d.).

The adoption or non-adoption of e-commerce, m-commerce, Social Media and ICT platforms by modern Kenyan women entrepreneurs is having a direct force on the failure, survival, growth or success of their entrepreneurial ventures. Many modern Kenyan women entrepreneurs accept that having a digital presence through online marketing and digital tools is vital to the survival of their ventures. Hence, online social networking and marketing campaigns when carried out 
and implemented at the right time and manner, in conjunction with the right e-commerce and m-commerce platforms, lead these women entrepreneurs to become successful. Identifying the proper use of the relevant technology and digital platforms in formal and informal setups, helps in finding out how technology and ICT apply to formal ventures when compared to informal ones.

Despite some hurdles, a significant feature in the Kenyan social scenery, which is mostly comprised of women known as Chamas or ROSCA's (Rotating Savings and Credit Associations) has benefitted from the use of mobile money through members using this means to contribute, save, get airtime and deposit remittances to the group or bank accounts. Through the mobile phones, balances are also checked and money received (Kusimba et al, 2013: 22). According to Rapelang Rabana (cited in Seko, $2013: 16$ ), "Entrepreneurship is a much more personal journey than it is a business journey". Rabana's passion is in technology and she sees herself starting diverse industries that are linked to technology against difficult odds and multitudinous barriers. Thus in her view, African women entrepreneurs must apply their creativity and innovation in the establishment of enterprises. In other words, they must forge new paths, design new careers, face new challenges and progress beyond the limits of global politics and new market economies.

Innovation and entrepreneurship with regards to mobile technologies and applications in Kenyan communities is advanced through mLab, similar to Mobile Web Ghana based in Ghana, which is a mobile entrepreneur lab in West Africa that focuses and promotes the interaction of entrepreneurs through digital technology within an internet space. Some technological entrepreneurs like Virtual Mobile Technologies, have created products or rather applications that enable clients to broaden distances they can cover, thereby enabling more contacts on their data base, the services they offer range from advertising, e-commerce, customer service and relationship management services to mobile gadgets. The focus of the platform is to enable the support of old phones, which will also help developing countries to also enjoy the services offered, since there is low internet and Smartphone penetration, but mobile gadgets have ample infiltration in the daily lives of the communities (WebFoundation n.d). These spaces have encouraged a lot of women entrepreneurs on the continent to research and finally learn to embrace and adopt technology for their ventures.

Women entrepreneurs have observed great transformation in their businesses after adopting mobile technology. The main drivers of this trend are improved business practices, increased competition and performance and new business opportunities (Komunte, Rwashana, \& Nabukenya, 2012 : 82). According to Webster's (1992) practical proficiencies including IT are essential subjects for conducting incorporated marketing operations. "The core firm will be defined by its end-use market and its knowledge base, as well as its technical competence, not by its factories and its office buildings. Customer focus, market segmentation, targeting and positioning, assisted by information technology, will be the flexible bonds that hold the whole thing together" (Webster, 1992:5 as cited in Saren, 2011:40). Existing ventures and new business opportunities are provided and can be accessed through the adoption of mobile phone service including mobile money, internet, emails etc (Komunte, Rwashana, \& Nabukenya, 2012: 82). In modern times small business retailers are enabling mobile shoppers to have access to their product offering through mobile stores. This proves that retailers have finally accepted that the digital age has introduced Mobile Driven Entrepreneurship.

As aforementioned, the research has been carried out on three case studies of women owned ventures based in Nairobi, Kenya. These businesses are formal and informal and have embraced the World Wide Web, or social media platforms or both. The presence of formal and informal businesses can be found all over Africa and thanks to the power of the Internet and social media platforms currently searching for diverse entrepreneurship ventures is not difficult. Both the informal and formal entrepreneurs who have embraced the internet and use of social media platforms can be observed, documented and compared. This allows the comprehension of the role played by the internet and Social Media platforms in the growth, expansion and success of entrepreneurs in Africa. Especially by entrepreneurs who are well versed in the rules and applications found online that has enabled them get ahead of their peers.

These aspects when critically studied could enable the established and upcoming entrepreneurs to realize that merely obtaining technology and adopting digital platforms will not grow their practices however, it is only when they practically play an active role in engaging with these platforms and spaces that these tools can enhance their growth and expansion. With the internet becoming a fundamental part of daily life on the African continent and especially in Kenya, people are beginning to change the way they communicate, shop, work, research and even socialise as attested by Olga Arara-Kimani (cited in Mulunda, 2012 :19). Dash2do, a mobile application that promotes e-commerce and m-commerce through an online platform with an existing portfolio of informal workers carry out daily tasks for the very busy professionals. The informal errand workers normally pay the company 30 percent of their fees and payment is through credit cards, PayPal for the Diaspora Kenyans and M-Pesa for locals (AfricaReport, 2013 ). Adopting and implementing technology in terms of mobile phones through data (information) based operation costs reduces poverty premium (KarrerRueedi \& Trueb, 2011:14). Women and the disadvantaged have been empowered through the use of mobile phones which have enabled easy communication, market access, sell products globally, reach more consumers and make mobile 
payments (West, 2012:1).

The outcome of a study on Activity theory for analysing mobile phone usage by women entrepreneurs is presented in Figure 1. This study was carried on women entrepreneurs who were discovered to operate on small enterprises in the informal sector, the mobile intervened in transactions involving MSEs. Telecommunications operators, ICT policies of the countries in which the research took place. The action that was taking place in these women ventures was transacting, the data and information obtained with the use of mobile phones enabled these women to produce results with regards to their businesses. The women entrepreneurs accomplished their objectives of maximizing their profits while reducing operational costs, which was achieved through Mobile communication. This mobile communication involved securing products, knowledge and experiences through this wireless gadget. Women entrepreneurs used the mobile phone to conduct their relations ships with the society around them and the various networks and relationships in the society they exist in, the society being the business environment in which they operate in (Komunte, Rwashana, \& Nabukenya, 2012 : 83).

Figure 1: Activity Theory -Based Assessment of Mobile Interaction on Women Entrepreneur Activity

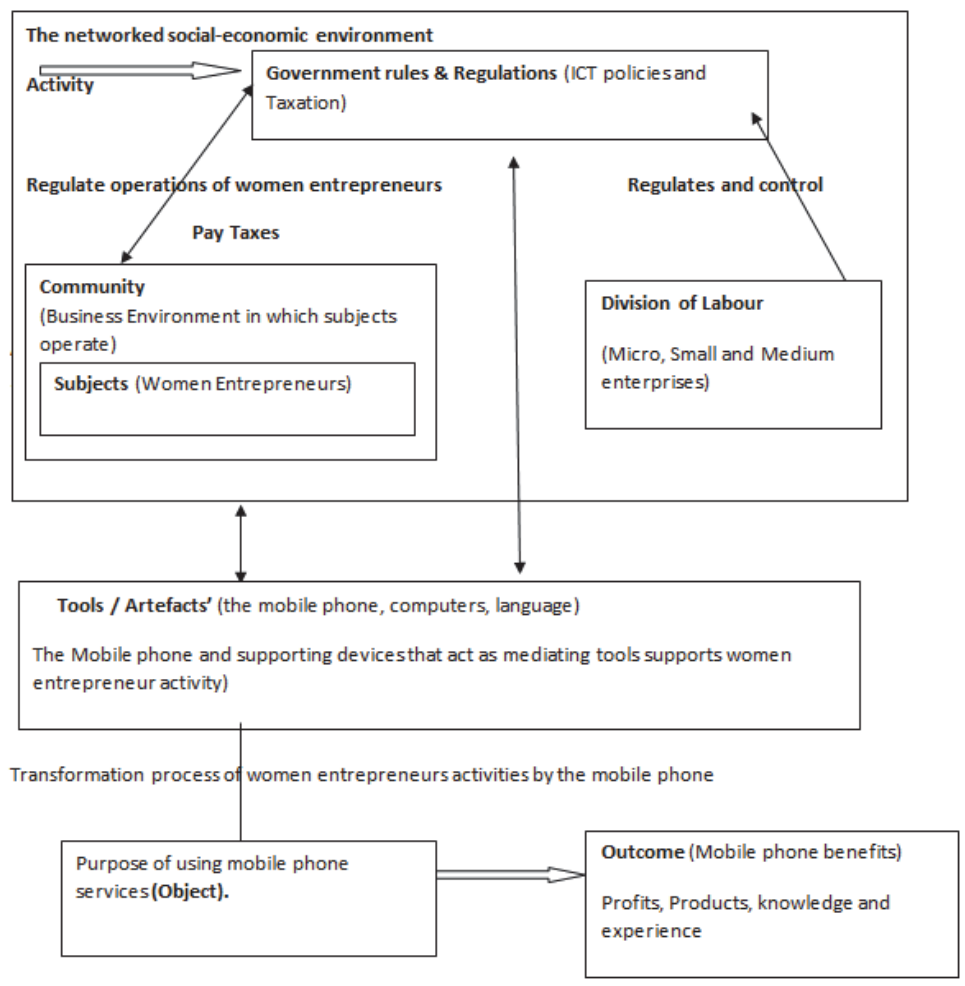

Source: Komunte, Rwashana,\& Nabukenya (2013: 83)

The Director of Hivecolab Barbra Birungi believes that when a woman is educated, the whole nation is ultimately educated. Due to the fact that women always tend to share the information obtained from other women and also passing on the content obtained to new generations. This is the reason why Birungi has become a strong advocate for women to be taught how to embrace and incorporate technology into their businesses so that the future women entrepreneurs can follow suit (Birungi 2012:1). In many African countries women entrepreneurs are playing an important part in the economic development of their countries, which includes Kenya. In Kenya, due to the cultural fact that most business women are not allowed to travel long distances without the permission of their husbands, technology has enabled this hurdle to be overcome by these women entrepreneurs without these traditions being broken.

When technology is used by women, African women entrepreneurs wider markets can easily and readily be accessed (Birungi 2012: 1). This makes it justifiable to argue that in order for Kenyan women entrepreneurs to improve their business ventures there is a need for them to be taught to embrace and utilise technology. This will ultimately lead to an improved and changed lifestyle. When African women adapt technology in their business ventures their understanding of globalisation is enhanced. Globalisation has resulted in the modern concept that the best performance relies solely on 
how technology and the digital tools that come with it are embraced and utilised on a daily basis.

Technology and digital tools enables Kenyan women entrepreneurs to be able to discover new markets opportunities that are created and accessed through the partnership of International and local businesses. Kenyan women entrepreneurs who deal in crafts and artefacts' can share, network and cooperate with fellow crafters from their neighbouring countries like Uganda as well as access new markets internationally (Birungi 2012: 1). Illustrations and case studies in developed economies have enabled most modern African women entrepreneurs to embrace technology and IT especially through Social Media platforms as a key to unlock the door to financial success in their ventures. Social Media platforms are considered as big business around the globe in various case studies. There are several barriers that have discouraged women entrepreneurs from embracing these Social Media platforms and these are depicted in Table1 below.

Table 1: Addressing Barriers to Women's Business Success

\begin{tabular}{|c|c|c|}
\hline & Most Frequent & Evolving \\
\hline Time & $\begin{array}{l}\text { - Home-based ICT businesses } \\
\text { - Flexibility and reach of mobile phones }\end{array}$ & $\begin{array}{l}\text { - Mobile-based business management } \\
\text { - Banking services via e-card }\end{array}$ \\
\hline $\begin{array}{l}\text { Access to } \\
\text { Markets }\end{array}$ & $\begin{array}{l}\text { - Link to markets information via mobiles } \\
\text { - Link to suppliers for product tie-ins via ICTs }\end{array}$ & $\begin{array}{l}\text { - Link to new markets and business opportunities via } \\
\text { mobiles and internet }\end{array}$ \\
\hline Social Norms & $\begin{array}{l}\text { - ICTs as acceptable and valued business venture } \\
\text { for women } \\
\text { - Information and skills sharing among women }\end{array}$ & $\begin{array}{l}\text { - Women as business role models } \\
\text { - Women as leaders and providers of services in } \\
\text { community }\end{array}$ \\
\hline $\begin{array}{l}\text { Skills and } \\
\text { Training }\end{array}$ & $\begin{array}{l}\text { - Online \& ongoing skill building in business and } \\
\text { ICTs }\end{array}$ & $\begin{array}{l}\text { - Business training and capacity building via mobiles } \\
\text { - Women friendly ICT-based tools for business }\end{array}$ \\
\hline $\begin{array}{l}\text { Finance and } \\
\text { Capital }\end{array}$ & $\begin{array}{l}\text { - Women-friendly banking products } \\
\text { - Financing for entrepreneurship } \\
\text { - Subsidizing start-up costs } \\
\end{array}$ & $\begin{array}{l}\text { - Women-friendly credit and savings products via ICTs } \\
\text { (e.g., e-card) }\end{array}$ \\
\hline $\begin{array}{l}\text { Business } \\
\text { Networks }\end{array}$ & & $\begin{array}{l}\text { - Mentoring services via mobile phones } \\
\text { - Strengthening Self Help Group networks through mobiles }\end{array}$ \\
\hline
\end{tabular}

Source: ICRW (2012: 59).

\section{Research Methodology}

Case studies that depict the use of technology by Kenyan based women entrepreneurs were undertaken. The Country (Kenya) in focus for the data collection is the economic powerhouse of the East African region. Online data was obtained through online questionnaires and financial data from 3 Kenyan based women entrepreneurs in different age categories. The data was obtained from these three different Kenyan women entrepreneurs with diverse business interests, who conduct their businesses in Nairobi, Kenya. As alluded earlier, one business is informal while the other two are formal. These three women entrepreneurs embraced technology and existing social platforms for their E-marketing and communication to reach and access their client base and interact with networks who will be converted to potential future clients. All the information obtained was done through the digital space with the aid of technology tools

The informal business is a retail or product based business dealing in women's fashionable and trendy shoe distributor with a strong Facebook personal page presence, which has been identified and featured as Celestial Trendz, while in the formal business space, a two service based business/venture basically in communication print media and television content, have also been incorporated in order to balance the business types to include service based and product based ventures. Each venture has been carefully analysed although the owners of one of the formal businesses does not want their names or their ventures documented, due to bankruptcy and failure of the business. However, adequate financial reports were provided for analysis. The featured businesses in the Film and Media industry have been targeted or identified and the age range of the women entrepreneurs were taken into account and specially considered. The internet is the chosen mode of obtaining the relevant information since it is easy to access, inexpensive and fast to get the data and evidence through questionnaires and personal contact through Facebook inbox interviews by way of random and carefully selected questions. 


\subsection{Informal venture celestial trendz}

Celestial Trendz is a Nairobi based informal venture specializing with women's shoes and accessories and some men's shoes. It was operating for 2 years prior to it being closed. It did not have a physical store but solely relied on Facebook personal page to display the images of the available items. The personal page was used in order to take advantage of the personal networks that she had and start from there as a client base and the rest was these networks referring the page by word of mouth. The payment solution that involved m-commerce was M-Pesa, while some items were paid upfront (COD). It embraced the internet and social media platform to interact with their existing customer base and prospective clients. This is also reflected in Figure 3 below.

Figure 3: Screenshot of Celestial Trendz (Informal business).



Sources: Celestial Trendz Facebook Source.

\subsection{Formal venture film and entertaimnet magazine}

A young lady within the age range of 20-25 years in Media who requested to remain anonymous due to the fact that her business, which is based in Nairobi had to be closed due to bankruptcy. She was in the film and media space based in Nairobi and published, printed and sold entertainment news (celebrity stories from the film industries of Nollywood in Nigeria, Ghallywood in Ghana and Riverwood in Kenya) content based magazine publishing company for two years prior to it getting closed.

\subsection{Formal venture talk show production}

Patricia Amira is a leading talk show host in Kenya who produces her own content for consumption through her show, the Patricia show that airs on MNET and is distributed globally through other channels in America and Europe. She has a Facebook company page plus a website for her company. Prior to this she held well-paying jobs at different media companies in the country before venturing into entrepreneurship by starting her own talk show programme and became self-employed.

\section{Discussions of Findings}

Kenya being seen as an East African business hub and the economic powerhouse of the region has been able to encourage entrepreneurs, especially women to embrace the digital tools through technology to enhance and improve their business ventures. This made it an ideal environment to base the observation and look at existing case studies in that environment.

The first case study of an informal business venture was carried out by the first author when she was in her late 30s. She started getting products from Cape Town and transported them by road to Kenya. When business opportunities 
around her presented themselves in various ways through her research, she discovered there were shoe wholesalers and suppliers located in Woodstock and Salt River area of Cape Town who sold left over branded shoes at reasonable rates to the public. This was an instant opportunity of selling shoes in Kenya to women at a reasonable price. She started sending shoes, handbags and sun glasses to Kenya through road freight, a journey that took a week maximum and the freight and custom charges were quite reasonable with no warehousing costs attached by the transporters. She started sending her products through this mode of transportation and decided to open a Facebook account to post the product pictures, price and quantity details of expected products; this in turn got her clients to order and pay upfront for the products through M-pesa a Kenyan mobile banking platform of Vodacom (Safaricom in Kenya). All this was an informal way of conducting her business that enabled meeting her immediate expenses. This for her was an eye opening experience on how technology through Social Media marketing and platforms can be exploited and used to the advantage of informal businesses, when applied on a formal venture and the its effect measured, it is a powerful way for future entrepreneurs to conduct their businesses while at the same time pursuing other vocations.

In terms of the second case study of the formal business that went bankrupt, the lady age group was between 2025 years. She was very young, inexperienced and has just graduated from university when she got a loan to start the venture. From analysing her finances, her priorities lay in using the funds for getting an office space, furniture, electronic gadgets, consumables, marketing and entertainment. This lead to income generated by the magazines sold after publishing to be used for offsetting very high overheads. Social platforms and website page for the company were opened and used but not to the maximum advantage of their worth. Office space and furniture could have been avoided by using these modern virtual office environments where a space and boardroom is booked from existing office rental space businesses that allow new entrepreneurs to use the facilities like phone and answering services and just use the office space when it comes to meetings. Initially this would have been very advisable as it would have greatly saved the cost on overheads.

Lastly the formalised entrepreneurial venture, namely a talk show and production company by Nigerian business space is quite interesting, this is due to the fact that the entrepreneurs who have incorporated the lady in question Patricia Amira is in her 30s and understands the power of technology to drive her venture. Although she admitted she knows enough to get by and employs professionals to handle the technology in her venture. She seems to feel out of depth with details that entail the technologies she uses in her production company, due to the fact that technology keeps evolving and changing all the time. Therefore, the professionals she employs are held accountable if things do not go as planned since it is their responsibility.

When Kenyan women entrepreneurs adapt and embrace technology they learn better business practises from their networks, which include financial management and business growth and diversification. This includes how to discover wider market opportunities economically in real time. Owing to the fact that most women owned ventures in Kenya employ the women's children and other women relations in the community this enables any technological or digital tool in use to be taught to a wider range of the people that are involved in the venture. It has been observed that Kenyan women entrepreneurs who experienced first-hand the benefits of the adoption of technology and digital tools in their ventures, always endeavour to encourage their children to take up subjects that involve technology in the higher learning programmes.

The informal Kenyan women entrepreneurs make use of m-commerce payment platforms of M-Pesa or any other existing mobile payment solutions available being offered by the existing telecommunication operators in the country. Online social platforms of Facebook, Pinterest, Whatsapp are used to advertise their products while orders and payments transactions are done through m-commerce methods or physically on delivery after orders have been placed on these platforms.

On the other hand the formalised ventures of Kenyan women entrepreneurs use e-commerce, m-commerce, and Social media based platforms including online payments, internet banking and E-marketing to advertise and reach a wider clientele as well as get access to new markets. They educate themselves adequately or employ the people with the right qualifications to manage these technological tools and digital platforms adequately. In this space it is observed that the entrepreneurs are informed in detail about the tools or applications that will work best for their ventures through the incorporation of technology, particularly for business in Kenya. This has been observed to apply in both the informal and formal business spaces.

This trend has been made possible for Kenyan women entrepreneurs to start their ventures informally and through the profits made by the venture to formalise them in due course. The phenomenon of using technology for business in Kenya by women entrepreneurs has been made possible through digital tools and incorporation of technology due to the availability of faster, cheaper internet speeds and data being offered by the major telecommunications companies, which operates in the country. This has enabled majority of the women entrepreneurs to take advantage of this privilege, 
thereby enabling them to be able to start a business informally before formalising it with the profit obtained through the informal structure, before thinking of expansion plans. Digital platforms have also enabled them to form forums for advice and networking that support them to get expert advice at their fingertips at the same time making use of the same for interacting with existing as well as meeting prospective clientele.

\section{Conclusion}

The use of technology by Kenyan women entrepreneurs is being seen as a very innovative aspect of their daily lives. Since women entrepreneurs are known to multitask in a lot of roles that incorporate their daily lives these roles range from being procreators, home managers and lastly entrepreneurs as business women running their own ventures. Technology has enabled them the luxury of being able to adequately manage their time and daily tasks enabling them to be present in all aspects of daily developments of their family and business spaces. The contemporary Kenyan woman entrepreneur is finding it very crucial and necessary to embrace and adapt technology in their daily lives and business ventures. Thus enabling them to have an advantage when compared to women who are not proactive enough to learn about technology or even think of incorporating it in their ventures. It has been observed on the African continent that men entrepreneurs have actively embraced and are applying technology to boost their business to their economic advantage and it is time for their women counterparts to do the same in order to gain the benefits and advantages that come with incorporating technology and digital platforms in their business space.

\section{References}

AfricaForbes. (2013). You are entitled to nothing. Cape Town: ABN Publishing.

AfricaReport. (2013). Start Up - Deeds done in Nairobi. Paris: Groupe Jeune Afrique.

Birungi, B. (2012, July 27). African women must use tech to change business. Retrieved December 21, 2013, from BBC News: http://www.bbc.co.uk/news/business-18926177

Cherie Blair Foundation for Women (CBFW) (2011). Women Entrepreneurs in Mobile Retail Channels: Empowering Women Driving Growth. London: Cherie Blair Foundation for Women (CBFW, STC, \& TNSRMS).

ICRW. (2012). How Mobile Phones, Computers and the Internet can Catalyze Women's Entrepreneurship. Washington D.C: The International Center for Research on Women (ICRW).

Karrer-Rueedi, E., \& Trueb, D. (2011 :15). Empowering micro-enterpreneurs and small businesses through mobile phones in emerging markets and developing countries. ATDF Journal Volume 8 Issue 3/4 , 13-18.

Komunte, M., Rwashana, A. S., \& Nabukenya, J. (2012 , September). Comparative Analysis of Mobileusage among Women entrepreneurs in Uganda and Kenya. African Journal of computing \& ICT, Vol 5, No 5. , 74-86.

Kusimba, S., Chaggar, H., Gross, E., \& Kunyu, G. (2013). Social Networks of Mobile Money in Kenya. IMTFI Institute of Mobile Money, Technology and Financial Inclusion , 1-33.

Legatum., I. (2011, May). The Role of Entrepreneurship and Opportunity in Sub Saharan Africa . Retrieved August 31, 2011, from Legatum Institute Website: http://www.li.com

Michira., M. (2011, May 27). High fliers must know their business, reinvent themselves and make friends. Retrieved from Business Daily.

Molony, T. (Summer 2006). "I dont trust teh phone; It always lies": Trust and Information and Communication Technologies in Tanzanian Micro-and small enterprises. Information Technologies and International Development archive, Vol 3, Issue 4, 67-83.

Mulunda, L. (2012 :19). The Queen of Africa Reboots, Africa Forbes. Cape Town: ABN Publishing.

Poterfield., A. (2010, August 31). Top 10 facebook pages. Retrieved September 10, 2011, from www.socialmediaexaminer.com: http://www.socialmediaexaminer.com/top-10-facebook-pages/

Rognerud., J. (2011, April 28). Big Cooprrate social media campaign that work. Retrieved September 10, 2011, from www.jonrognerud.com: http://www.jonrognerud.com/big-cooporate-socia- media-campaign-that-work/

Saren., M. (2011). Marketing empowerment and exclusion in the information age. Marketing Intelligence \& Planning Vol. 29 No. 1 , Emerald Group Publishing Limited, 39-48.

Seko, L. (2013 ). Dont Patronize Us, Africa Forbes. Cape Town: ABN Publishing.

Ukpere, C., \& Slabbert, A. (2014 yet to be published). The use of Technology by African women entrepreneurs and in changing business through M-commerce/E-commerce/Technology. Research Thesis . Cape Town, Western Cape, South Africa: CPUT.

WebFoundation. (n.d.). Projects Mobile entrepreneurship. Retrieved November 30, 2013, from WorldWideWebFoundation.org: http://www.webfoundation.org/projects/mobile-entrepreneurship/

Webster., F. E. (1992). The changing role of marketing in the corporation . . Journal of Marketing, Vol. 56, October, , 1-17.

West, D. M. (2012 : 6). How Mobile Technology id driving global entrepreneurship. Governance studies , 1-10.

Womenable. (2010, December 13). Women Business Owners Embrace Social Media Marketing. Retrieved September 3, 2013, from The women enabler blog: www.thewomenablerblog.com/2010/12/ 